\title{
Cut gladiolus postharvest using holding solutions with calcium
}

\section{Conservação pós-colheita de gladíolos utilizando soluções de manutenção com cálcio}

\section{Maria Carolina CÁSARES ${ }^{1 ; 2}$; Ana Carolina Corrêa MUNIZ3; Claudia Fabrino Machado MATTIUZ4; Ben-Hur MATTIUZ ${ }^{5}$}

${ }^{1}$ Parte da tese de doutorado do primeiro autor.

2 Doutora; Universidad Centroccidental Lisandro Alvarado UCLA: Posgrado de Agronomía, Venezuela.

${ }^{3}$ Engenheiro Agrônomo, M. Sc.; Universidade Estadual Paulista UNESP-FCAV.

${ }^{4}$ Doutora; Escola Superior de Agricultura Luiz de Queiroz ESALQ/USP, Departamento de Produção Vegetal

${ }^{5}$ Autor para correspondência; Doutor; Universidade Estadual Paulista UNESP-FCAV; Departamento de Tecnologia, Laboratório de Pós-Colheita; Via de acesso Paulo Donato Castellane;benhur@fcav.unesp.br

Recebido em: 08-01-2015; Aceito em: 30-04-2016

\begin{abstract}
Calcium $\left(\mathrm{Ca}^{2+}\right)$ is an essential nutrient for plants, necessary in the structure of cell wall and membrane. Use of calcium in postharvest has been a successful alternative to maintain quality and delaying senescence in cut flowers. Holding solutions improve longevity and quality of cut flowers and generally contain carbohydrates, germicide and plant growth regulators, among other substances that can maintain or regulate metabolism after cutting. It was evaluated the effect of calcium in holding solution on longevity and quality of 'White Friendship' gladiolus cut inflorescences. Inflorescences harvested with all flowers completely closed were placed in the following holding solutions: distilled water; [sucrose (4\%) (S)] + [germicide $\left(0.66 \mathrm{mg} \mathrm{L}^{-1}\right.$ of sodium dichloroisocyanurate dihydrate) $(\mathrm{G})] ;\left[\mathrm{S}+\mathrm{G}+0.1 \% \mathrm{CaCl}_{2}\right]$; and $\left[\mathrm{S}+\mathrm{G}+0.2 \% \mathrm{CaCl}_{2}\right]$ and hold in ambient conditions of $21,2 \pm 0,2{ }^{\circ} \mathrm{C}$ and $66 \pm 4 \% \mathrm{RH}$. Longevity, daily and average ornamental values, floral opening rate, postharvest inflorescence development, fresh weight and membrane stability index were evaluated every three days until the wilting of the third flower from the base of the inflorescence. Holding solutions with or without calcium obtained similar results in all variables, with differences only with the use of distilled water. Use of calcium in holding solution was not efficient to increase longevity or improve quality of gladiolus cut inflorescences.
\end{abstract}

Additional keywords: germicide; membrane stability index; quality; sucrose; vase life.

\section{Resumo}

O cálcio $\left(\mathrm{Ca}^{2+}\right)$ é um nutriente essencial para as plantas, necessário na estrutura da parede e da membrana celular. O uso de cálcio na pós-colheita tem sido uma alternativa de sucesso para manter a qualidade e retardar a senescência em flores cortadas. As soluções de vaso melhoram a longevidade e a qualidade das flores cortadas, geralmente contêm carboidratos, germicidas, reguladores vegetais, entre outras substâncias que sustentam ou regulam o metabolismo após o corte. Avaliaram-se o efeito do cálcio na solução de manutenção na longevidade e a qualidade das inflorescências de gladíolo 'White Friendship'. Inflorescências com todas as flores completamente fechadas foram colocadas nas seguintes soluções: água destilada; sacarose $(4 \%)(\mathrm{S})+$ germicida $\left(0,66 \mathrm{mg} \mathrm{L}^{-1}\right.$ de dicloroisocianurato de sódio di-hidratado) $(\mathrm{G}) ; \mathrm{S}+\mathrm{G}+\mathrm{CaCl}_{2}$ $0,1 \% ; \mathrm{e} \mathrm{S}+\mathrm{G}+\mathrm{CaCl}_{2} \mathrm{0,2} \%$, e mantidas em condições de ambiente de $21,2 \pm 0,2^{\circ} \mathrm{C}$ e umidade relativa de $66 \pm$ $4 \%$. Longevidade, desenvolvimento da inflorescência (botões mostrando a cor, flores abertas e murchas), massa fresca, relações hídricas (solução absorvida, perda de água e balanço hídrico) e índice de estabilidade da membrana foram avaliados a cada três dias até o murchamento da terceira flor da base da haste. As soluções de manutenção, com ou sem cálcio, obtiveram resultados similares em todas as variáveis avaliadas, tendo diferenças apenas com o uso de água destilada. O uso de cálcio na solução de manutenção não foi eficiente para aumentar a longevidade nem a qualidade das inflorescências de gladíolo.

Palavras-chave adicionais: germicida; índice de estabilidade da membrana; qualidade; sacarose; vida útil.

\section{Introduction}

The vessel solutions enhance the longevity of cut flowers by providing compounds necessary for the maintenance or the regulation of metabolic processes. Usually these solutions contain a source of carbohydrates, an acidifying agent and bactericidal compounds, among others (Silva, 2003).

The calcium $\left(\mathrm{Ca}^{2+}\right)$ is an essential nutrient for the plants that is needed in the cell wall and cell membrane structure, among others. As a secondary messenger, the ion calcium participates in events that lead to the appropriated growth and development. The calcium plays an essential structural role 
in the architecture of the cell wall, while its availability provides structural integrity to the stability of the membrane. The supply of calcium also increases the longevity of the flowers by retarding the senescence and reducing the ethylene production. (Hepler, 2005; Aghdam et al., 2012).

The use of calcium in the postharvest has been a successful alternative to maintain the quality and to delay the senescence in cut flowers of gerbera (González-Aguilar \& Zavaleta-Mancera, 2012), alpinia (Silva et al., 2009), rose (Dias \& Patil, 2003; Mortazavi et al., 2007, Huerta et al., 2011) and gladiolus (Bai et al., 2009;. Sairam et al., 2011).

The objective of this study was to evaluate the development and the postharvest life of inflorescences of gladiolus 'White Friendship' in maintenance solutions with calcium.

\section{Material and methods}

Inflorescences of gladiolus 'White Friendship', taken with all the flowers closed (commercial harvest point), the stems were obtained from a commercial producer in May 2013 in the region of Vargem Grande do Sul (21ํำ'28 "S and 4653'59.81 "W, and an altitude of $710 \mathrm{~m}$ ), São Paulo, Brazil. They were transported in containers containing tap water in an upright position and in vehicle with air conditioning to the laboratory within six hours after the harvest. The inflorescences were standardized to $80 \mathrm{~cm}$ long, cutting them underwater, and immediately placed in the maintenance solutions. The following solutions were used:

- Distilled water;

- 4\% Sucrose + $0.66 \mathrm{mg} \mathrm{L}^{-1}$ of sodium

dichloroisocyanurate dihydrate $6.25 \%$ (Sumaveg $^{\circledR}$ );

- $4 \%$ Sucrose $+0.66 \mathrm{mg} \mathrm{L}^{-1}$ of sodium

dichloroisocyanurate dihydrate $6.25 \%$ (Sumaveg $^{\circledR}$ )

+ Calcium chloride $\left(\mathrm{CaCl}_{2}\right) 0.1 \%$ e

- $4 \%$ Sucrose $+0.66 \mathrm{mg} \mathrm{L}^{-1}$ of sodium

dichloroisocyanurate dihydrate $6.25 \%$ (Sumaveg $^{\circledR}$ )

+ Calcium chloride $\left(\mathrm{CaCl}_{2}\right) 0.2 \%$

The inflorescences were kept in the solutions and in environmental conditions of $21.2 \pm 0.2^{\circ} \mathrm{C}$ and relative humidity of $66 \pm 4 \%$. The experimental design was completely randomized with 4 maintenance solutions and 3 evaluation dates, three replicates and three inflorescences per repetition. The evaluations were performed every three days (3, 6 and 9 days) and the initial volume $(500 \mathrm{~mL})$ of all solutions was completed each day of evaluation. The following variables were considered:

Postharvest life or longevity: Was defined by the number of days until the wilting of the third flower of the base of the inflorescence (Serek et al., 1994).

Daily Ornamental Value (DOV): It was calculated as the sum of the ornamental value (notes) of each flower in the inflorescence. Note 1: The exposed width of the tepals should be equal to the bracts or the flower is starting senescence; Note 2: the flower begins to open; Note 3: fully opened flower. It was regarded as the end of life when the DOV reached a value equal or less than 6 . The Medium Ornamental Value (MOV) was calculated with the DOV divided by the number of flowers in the inflorescence. The Floral Opening Rate (FOR) was calculated by the number of flowers opening divided by the total number of flowers in the inflorescence (Bai et al., 2009).

Postharvest Development of the inflorescences: Defined by counting the number of buds showing the color, fully open flowers and wilting flowers (Serek et al., 1994).

Fresh Weight: It was measured by weighing the three inflorescences of each repetition, using an electronic balance (Imsabai et al., 2013).

Water Relations: It was determined the absorbed solution (difference of the final and the initial volume of solution in each evaluation day), water loss (difference of the final and initial weight of the inflorescences on each evaluation day) and water balance (difference between the absorbed solution and the loss water) (Imsabai et al., 2013).

Membrane Stability Index (MSI): It was determined in five tepals disks of the third flower of the base of the inflorescence, which were washed and placed in incubation in $5 \mathrm{~mL}$ of deionized water for three hours at room temperature. After the incubation, it was measured the electrical conductivity of the solution ( $A$ value). The solution and the discs were placed in boiling water bath for 15 minutes. Allowed to cool the solution and the electrical conductivity it was measured again ( $B$ value). The membrane stability index was calculated by the following formula (Singh et al., 2008):

MSI $(\%)=[1-($ A value/B value $)] \times 100$

Data were submitted to analysis of variance and means were compared by Tukey test at $5 \%$ probability.

\section{Results and discussions}

Postharvest life of the inflorescences. The use of maintenance solutions did not get effect on the longevity of the inflorescences of gladiolus, which had postharvest life between 8.7 and 9.7 days (Table 1). These results are similar to those obtained by Akbudak \& Murat (2012) that concluded that the calcium ("pulsing" with $\mathrm{CaCl}^{2} 0.1 \%$ for 16 hours) had no effect on the useful life of gerberas 'Rosalon' after 28 and 35 days of storage and 7 days in vessel. Equally, Hatamzadeh \& Shafyii-Masouleh (2013) reported that the maintenance solution with calcium sulfate (10 or $20 \mathrm{mM}$ ) had no effect on the useful life of gerbera 'Pink Elegance'.

The results of this study were different from those obtained by González-Aguilar \& Zavaleta-Mancera (2012) in gerberas 'Duela' and 'Shirlane', in which the use of calcium chloride increased the shelf life of the inflorescences, and from those presented by 
Chutichudet \& Chutichudet (2012), that found that the chloride and phosphate acid of calcium reduced the longevity in Curcuma alismatifolia 'Chiang Mai Pink'.

In gladiolus, Bai et al. (2009) found that calcium chloride extended the shelf life and the postharvest quality of the cultivar Mascagni, considering the daily ornamental value (DOV), medium (MOV) and the flowers open rate in the inflorescence. It is possible that the method used in this study is not appropriated for the gladiolus 'White Friendship' because it defines that the shelf life of the stem ends when the DOV is less than 6, however for the inflorescences of this work, the smaller DOV in the evaluation of the $9^{\text {th }}$ day was 14 (distilled water), whereas for other solutions the values were between 23 and 27 and resulted statistically equal, although the inflorescences in all treatments showed extensive damage and undesirable appearance. The floral opening rate (FOR) was higher in the solutions containing calcium and germicide, only in the assessment of the $9^{\text {th }}$ day.

Table 1 - Effects of calcium concentration in holding solution (T), evaluation day (D) and interaction (TxD) on shelf life, fresh weight, inflorescence postharvest development (showing-color buds, fully-open and wilting flowers), water relations (solution uptake, water loss, water balance) and membrane stability index, in Gladiolus $x$ hortulanus 'White Friendship' cut inflorescences.

\begin{tabular}{|c|c|c|c|c|c|c|}
\hline \multirow{3}{*}{ Source of Variation } & \multicolumn{6}{|c|}{ Significance level for the $\mathrm{F}$ test } \\
\hline & \multirow[b]{2}{*}{ Shelf Life } & \multicolumn{4}{|c|}{ Inflorescence development } & \multirow[b]{2}{*}{ Fresh weight } \\
\hline & & \multicolumn{2}{|c|}{ Showing-color buds } & $\begin{array}{l}\text { Fully-open } \\
\text { flowers }\end{array}$ & Wilting flowers & \\
\hline Treatment $(\mathrm{T})$ & n.s. & \multicolumn{2}{|c|}{ ** } & ** & n.s. & ** \\
\hline Evaluation Day (D) & - & \multicolumn{2}{|c|}{$* *$} & $\star *$ & ** & ** \\
\hline$T \times D$ & - & \multicolumn{2}{|c|}{ n.s. } & * & n.s. & n.s \\
\hline \multirow{2}{*}{ Source of Variation } & \multicolumn{5}{|c|}{ Water Relations } & \\
\hline & \multicolumn{2}{|c|}{ Solution Uptake } & Water Loss & \multicolumn{2}{|c|}{ Water Balance } & \\
\hline Treatment (T) & \multicolumn{2}{|l|}{ ** } & n.s. & \multicolumn{2}{|c|}{ ** } & ** \\
\hline Evaluation Day (D) & \multicolumn{2}{|l|}{ ** } & ** & \multicolumn{2}{|c|}{ ** } & ** \\
\hline$T \times D$ & \multicolumn{2}{|l|}{ ** } & $* *$ & \multicolumn{2}{|c|}{$* *$} & ** \\
\hline
\end{tabular}

${ }^{*}$ significant at $5 \%$ of probability; ${ }^{*}$ significant at $1 \%$ of probability; n.s. non-significant.

Sairam et al. (2011) found that the use of calcium chloride increased the longevity of gladiolus 'White Prosperity', whereas that the inflorescence keeps the ornamental value until the fresh weight is less than that recorded at the beginning of the experiment. Considering this criterion in this work, only the inflorescences kept in distilled water would present shelf life of 9 days, while the stems held in solutions with sucrose, germicides and calcium would have a higher longevity (Figure 2), even with equal amounts of wilted flowers on the stem and the quality of the inflorescences was greatly reduced (Table 2).

Postharvest development of the inflorescences. The addition of germicidal compounds and calcium to the maintenance solution had effect on the number of buds showing the color and on the number of open flowers, what did not affect the number of wilted flowers (Table 1). The minor number of buds showing the color (Table 2) and of open flowers (Figure 1) was found in the control treatment with distilled water, from the $6^{\text {th }}$ day of evaluation.

Similarly, Bai et al. (2009) found that the use of calcium (acetate, $2 \mathrm{mmol} \mathrm{L}^{-1}$ ) resulted in the high- est rates of flower openings and ornamental value in Gladiolus hybridus 'Mascagni'. However, Amini et al. (2013) reported that the use of calcium chloride plus sucrose in gerbera, resulted in lower quality of the inflorescence, evidenced by a smaller diameter of the chapter.

The evaluation day affected all postharvest development parameters of the inflorescence (showing-color buds, fully-open flowers and wilting flowers) (Table 1). The inflorescences kept in the solution with $0.1 \%$ of calcium chloride showed the highest number of buds showing the color and open flowers on the evaluations of the days 6 and 9 , respectively. The largest number of wilted flowers was shown on the ninth day, not showing significant differences between the treatments (Table 2).

Fresh Weight. The use of maintenance solutions affected the fresh weight of the inflorescences of gladiolus (Table 1). The treatments with sucrose+germicide e sucrose+germicide $+\mathrm{CaCl}_{2}$ $(0,1 \%)$ showed equal fresh weight values between them and higher than those of the inflorescences kept in distilled water (Table 2; Figure 2). 


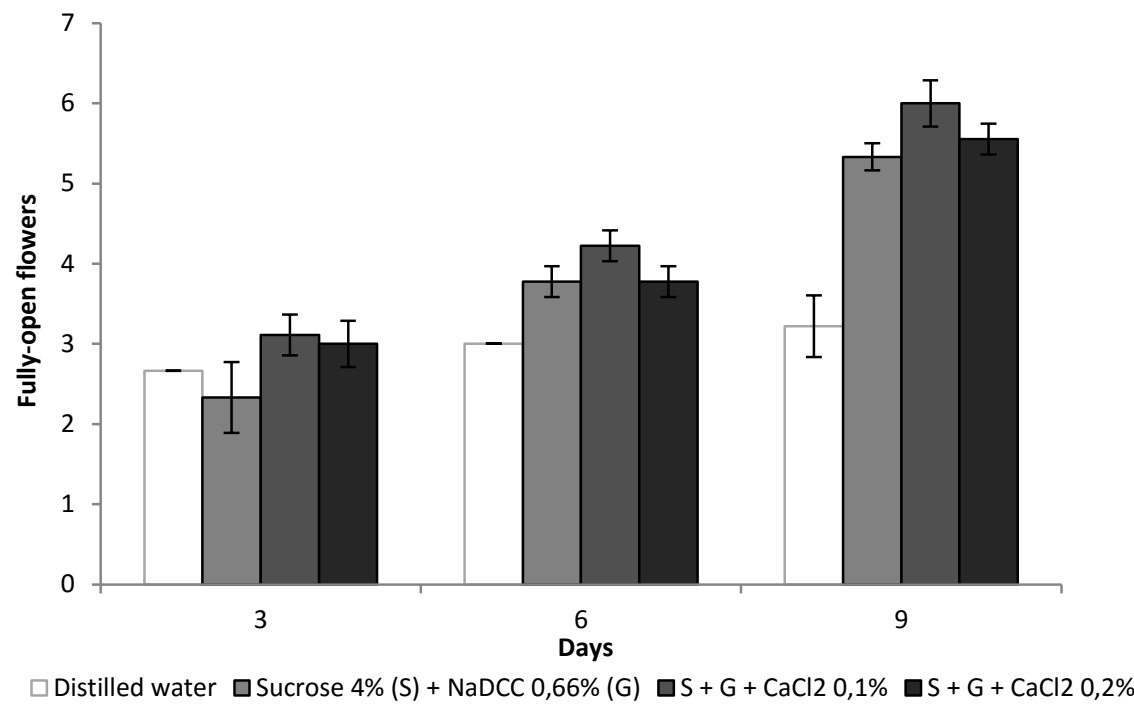

Figure 1 - Fully-open flowers in gladiolus cut inflorescences (Gladiolus $x$ hortulanus) in holding solutions with or without calcium at 3; 6 and 9 days of evaluation.

Table 2 - Fresh weight, postharvest development (showing-color buds and wilting flowers), membrane stability index and water relations (solution uptake and water loss) in Gladiolus $x$ hortulanus 'White Friendship' cut inflorescences in holding solutions with or without calcium $\left(\mathrm{CaCl}_{2} 0,1\right.$ e $\left.0,2 \%\right)$ at $3 ; 6$ and 9 days of evaluation.

\begin{tabular}{|c|c|c|c|c|c|c|}
\hline \multirow{3}{*}{ Treatments } & \multicolumn{6}{|c|}{ Evaluation Days } \\
\hline & 3 & 6 & 9 & 3 & 6 & 9 \\
\hline & \multicolumn{3}{|c|}{ Fresh weight of the inflorescence } & \multicolumn{3}{|c|}{ Showing-color buds } \\
\hline Distilled water & $212,3 \mathrm{Aa}$ & $198,6 \mathrm{Ba}$ & $173,6 \mathrm{Bb}$ & 4,6 Aa & $4,7 \mathrm{Ba}$ & $1,2 \mathrm{Bb}$ \\
\hline $\begin{array}{l}\text { Sucrose } 4 \%(S)+\text { NaDCC } \\
0,66 \%(G)\end{array}$ & $239,4 \mathrm{Aa}$ & $277,1 \mathrm{Aa}$ & $292,9 \mathrm{Aa}$ & 4,6 Aa & 5,7 Aba & $3,9 \mathrm{Ab}$ \\
\hline$(\mathrm{S})+(\mathrm{G})+\mathrm{CaCl}_{2} 0,1 \%$ & $230,1 \mathrm{Aa}$ & $263,9 \mathrm{Aa}$ & $273,6 \mathrm{Aa}$ & 6,1 Aa & $6,7 \mathrm{Aa}$ & $3,6 \mathrm{Ab}$ \\
\hline \multirow[t]{2}{*}{$(\mathrm{S})+(\mathrm{G})+\mathrm{CaCl}_{2} 0,2 \%$} & $226,1 \mathrm{Aa}$ & $254,5 \mathrm{ABa}$ & $263,8 \mathrm{Aa}$ & $5,6 \mathrm{Aa}$ & $5,9 \mathrm{ABa}$ & $2,8 \mathrm{ABb}$ \\
\hline & \multicolumn{3}{|c|}{ Wilting flowers } & \multicolumn{3}{|c|}{ Solution uptake } \\
\hline Distilled water & $0,0 \mathrm{Ac}$ & $1,6 \mathrm{Ab}$ & $5,2 \mathrm{Aa}$ & $102,4 \mathrm{Aa}$ & $35,3 \mathrm{Bb}$ & $6,5 \mathrm{Bc}$ \\
\hline $\begin{array}{l}\text { Sucrose } 4 \%(S)+\text { NaDCC } \\
0,66 \%(G)\end{array}$ & $0,0 \mathrm{Ab}$ & $1,1 \mathrm{Ab}$ & $4,7 \mathrm{Aa}$ & $96,0 \mathrm{Aa}$ & $71,6 \mathrm{Aa}$ & $66,5 \mathrm{Aa}$ \\
\hline$(\mathrm{S})+(\mathrm{G})+\mathrm{CaCl}_{2} 0,1 \%$ & $0,0 \mathrm{Ac}$ & $1,4 \mathrm{Ab}$ & 5,3 Aa & $94,3 \mathrm{Aa}$ & 70,7 Aab & $63,5 \mathrm{Ab}$ \\
\hline \multirow[t]{2}{*}{$(\mathrm{S})+(\mathrm{G})+\mathrm{CaCl}_{2} 0,2 \%$} & $0,0 \mathrm{Ab}$ & $1,8 \mathrm{Aab}$ & $4,1 \mathrm{Aa}$ & $88,5 \mathrm{Aa}$ & $66,0 \mathrm{Ab}$ & $57,3 \mathrm{Ab}$ \\
\hline & \multicolumn{3}{|c|}{ Water Loss } & \multicolumn{3}{|c|}{ Membrane Stability Index } \\
\hline Distilled water & $74,0 \mathrm{Aa}$ & $46,7 \mathrm{Ab}$ & $34,7 \mathrm{Ac}$ & $80,7 \mathrm{Aa}$ & $64,3 \mathrm{Aab}$ & $55,1 \mathrm{Ab}$ \\
\hline $\begin{array}{l}\text { Sucrose } 4 \%(\mathrm{~S})+\mathrm{NaDCC} \\
0,66 \%(\mathrm{G})\end{array}$ & 63,9 Aba & $33,7 \mathrm{Ab}$ & $51,6 \mathrm{Aa}$ & $84,6 \mathrm{Aa}$ & $37,6 \mathrm{Bb}$ & $10,6 \mathrm{Bc}$ \\
\hline$(\mathrm{S})+(\mathrm{G})+\mathrm{CaCl}_{2} 0,1 \%$ & $63,6 \mathrm{Aba}$ & $36,5 \mathrm{Ab}$ & $53,4 \mathrm{Aab}$ & 73,4 Aba & $42,3 \mathrm{ABb}$ & $16,6 \mathrm{Bc}$ \\
\hline$(\mathrm{S})+(\mathrm{G})+\mathrm{CaCl}_{2} 0,2 \%$ & $58,7 \mathrm{Ba}$ & $36,6 \mathrm{Aa}$ & 48,3 Aa & $60,9 \mathrm{Ba}$ & $45,1 \mathrm{ABb}$ & $7,9 \mathrm{Bc}$ \\
\hline
\end{tabular}

Mean values followed by different letters (capital on columns; minor on lines) are different by Tukey test at $5 \%$ probability.

The present results are similar to those reported by Dias \& Patil (2003) who concluded that the use of sucrose $(3 \%)$ and calcium chloride $(2 \mathrm{mM})$ increased the fresh weight of roses 'Arjun' after 6 days at the vessel. Sairam et al. (2011) reported that in gladiolus 'White Prosperity', the use of calcium chloride favored the gain of fresh weight after four days in the vase. Akbudak \& Murat (2012) found that calcium $\left(\mathrm{CaCl}_{2}, 0.1 \%\right.$, "pulsing" for 16 hours) reduced the weight loss in gerbera 'Rosalon' after 21; 28 and
35 days of storage and 7 days in vessel. Similarly, Chutichudet \& Chutichudet (2012) and GonzalezAguilar \& Zavaleta-Mancera (2012) using calcium chloride, obtained a lower loss of fresh weight in inflorescences of Curcuma alismatifolia and gerbera, respectively. While Amini et al., (2013) reported that gerberas maintained in solution with calcium chloride plus sucrose showed lower fresh weight than those kept in distilled water, after 9 days in vessel. 


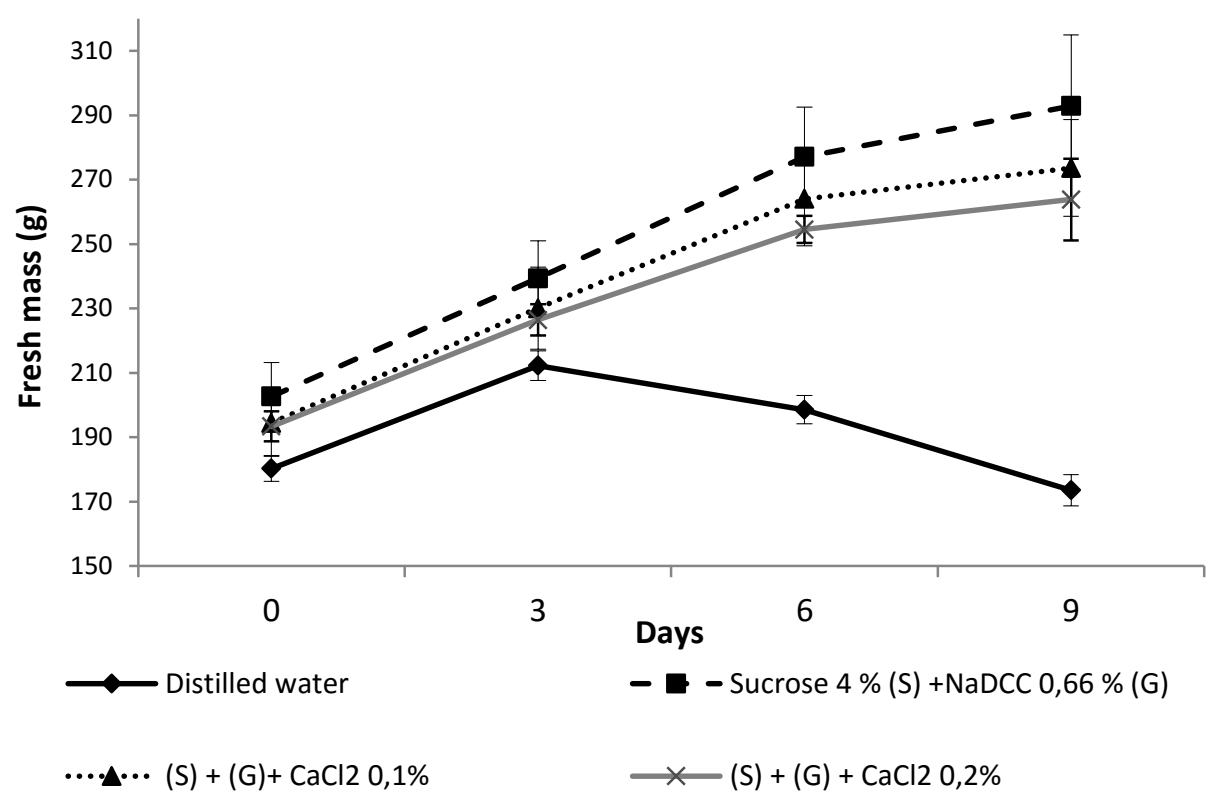

Figure 2 - Fresh weight of gladiolus (Gladiolus $x$ hortulanus) cut inflorescences in holding solutions with or without calcium at $0 ; 3 ; 6$ e 9 days of evaluation.

The treatment with calcium did not influence in the fresh weight of the inflorescences, since there was no statistical difference between the treatments with calcium and the control treatment (distilled water) (Table 2). This indicates that the increase in the fresh weight was probably due to the effect of the combination of sucrose + germicide, and not due to the presence of calcium in the maintenance solution.

The evaluation day influenced the fresh weight of the inflorescences of gladiolus (Table 2). The inflorescences kept in distilled water showed the lowest values of fresh weight from the $6^{\text {th }}$ day of evaluation. The fresh weight of the inflorescences kept in the solutions with sucrose, germicide and calcium did not show differences between them and were higher than the control. These results are similar to those obtained by Huerta et al. (2011) who found that the maintenance solution with sucrose $(4 \%)$, germicide (HQS) and calcium chloride remained unchanged in the fresh weight of roses 'Grand Gala' for up to 5 days.

Water relations. The maintenance solutions affect the solution uptake and the water balance (Figure 3 ) in the inflorescences of gladiolus, while the water loss (estimated transpiration) was not affected (Table 1).

The amount of absorbed solution was smaller in the treatment with distilled water; and the solutions with sucrose, germicide and calcium were significantly higher and equal between them (Table 2). These results are similar to those reported by Dias \& Patil (2003) that found higher solution uptake when it was used calcium chloride or sucrose as a maintenance solution. However, Chutichudet \& Chutichudet (2012) reported lower values of absorp- tion in Curcuma alismatifolia in the solution with calcium chloride $(0.8 \%)$ than in the control (distilled water), after 6 days in vessel. While Hatamzadeh \& Shafyii-Masouleh (2013) found no effect of the calcium sulfate in the maintenance solution in the amount of absorbed solution per inflorescence of gerbera 'Pink Elegance'.

The water loss results (estimated transpiration) found in this work are contrary to what was found by Dias \& Patil (2003) and Hatamzadeh \& Shafyii-Masouleh (2013), that reported that the use of calcium chloride or sulfate in the maintenance solution reduced the water loss in rose 'Arjun' and in gerbera 'Pink Elegance'.

The water balance values of the inflorescences were negative (more water loss than absorbed solution) from the $6^{\text {th }}$ day of evaluation for the inflorescences kept in distilled water, however, for the stems held in the other solutions, still in the $9^{\text {th }}$ day of evaluation, the water balance remained positive (greater absorbed solution than water loss) (Figure 3), suggesting that the wilting and the end of life of the flowers may be due to different causes to unfavorable water relations (Van Doorn, 2011).

The transpiration flow through the xylem of the vegetables is the most important route for the transport of calcium in the plants, then tissues with a low transpiration or which act as drains may have insufficient levels of this element (Baas et al., 2000; Kerton et al., 2009). In some monocots, the predominant flow goes to the leaves and can occur a high accumulation of calcium in the apex without the possibility of being recycled (White \& Broadley, 2003; Frickle, 2004; Kerton et al., 2009). 


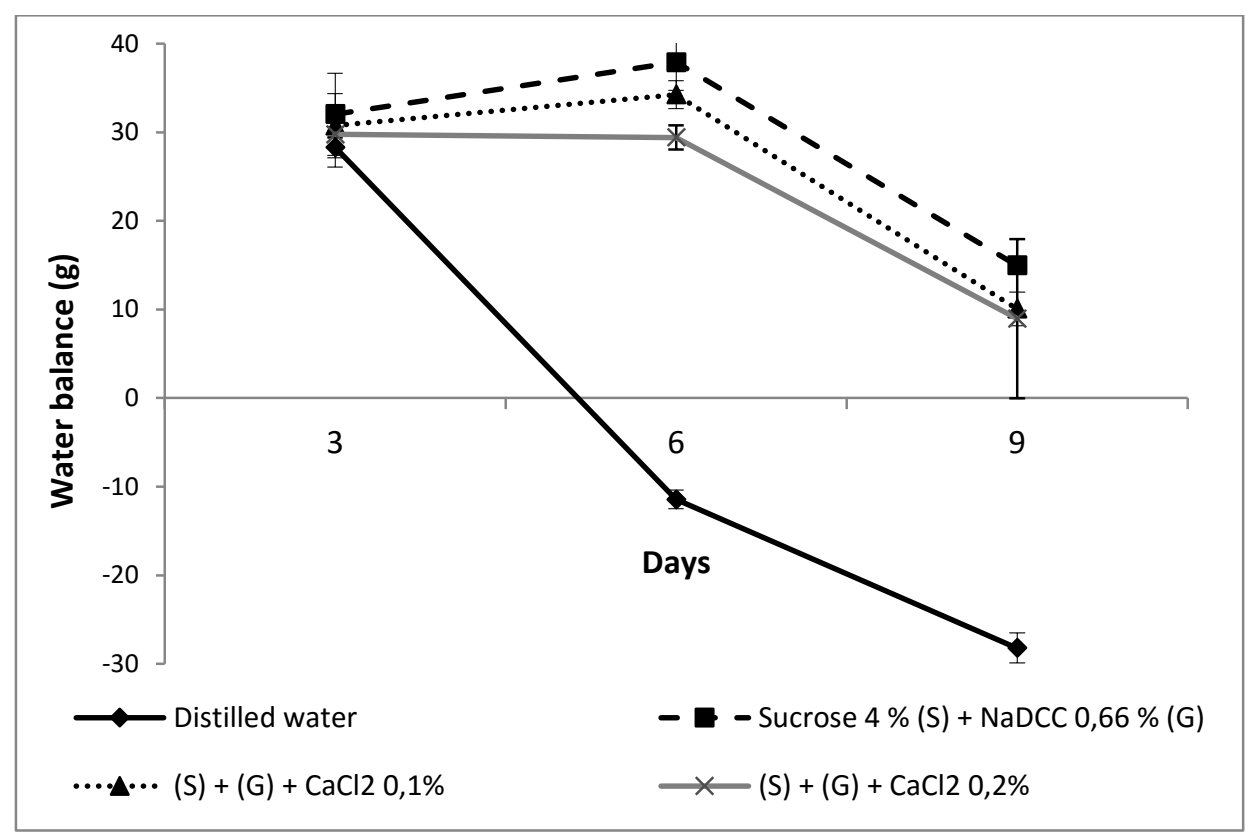

Figure 3 - Water balance in cut gladiolus (Gladiolus $x$ hortulanus) inflorescences in holding solutions with or without calcium at 3,6 and 9 days of evaluation.

Gilliham et al. (2011) stated that in some situations, it is possible that the symplastic long-distance transport is unable to lead enough calcium to tissues with low transpiration, especially when competing with others who have higher transpiration rates. It is possible that in the gladiolus, the calcium has followed this route and its accumulated in the leaf tissue preferably, reducing the possibility of having a positive effect on the flowers of the stem.

Membrane Stability Index (MSI). The maintenance solutions affected the MSI (Table 1). The highest values were recorded in the inflorescences kept in distilled water and the lowest values in the solutions with sucrose, germicide and calcium (Table 2). These results are contrary to those reported by Lin and Kuo (2008), Bai et al. (2009) and Sairam et al. (2011), who found that the use of calcium (chloride or acetate) increased the stability and the integrity of the membrane in rose 'Noblesse' and in gladiolus 'Mascagni' and 'White Prosperity', respectively. The lowest values of $\mathrm{MSI}$ in the maintenance solutions differents from the control (distilled water) may indicate a possible negative effect of the compounds on the membrane integrity.

The lack of effect of the calcium application in the maintenance solution may be due to the fact that even though the flow transpiration is an important factor in the calcium transport in the xylem, the absorption of this element is not always proportional to the movement of the water in the tissue (Yang et al., 2011). The already mentioned lack of redistribution, together with the difficulties in the transport can lead to local calcium deficiencies even if there is an abundant availability (Dayod et al., 2010).

The evaluation day affected the MSI (Table 1), so the stability decreased during the days of evaluation, for all treatments, which may be due to the progress of the senescence of the individual flowers (Table 2). These results are similar to those reported by Ezhilmathi et al. (2007) in gladiolus 'Green Willow', where the MSI rapidly declined with the senescence advance. When the petals wilt, the cell membranes progressively lose its integrity and occurs the loss of pigments, nutrients and electrolytes (Rubinstein, 2000), which increases the electrical conductivity and consequently, reduces the MSI values.

\section{Conclusions}

The use of calcium in maintenance solution had no effect on the longevity and the quality of the inflorescences of gladiolus. The best postharvest development (larger number of buds showing the color and open flowers) seems to be due to the use of sucrose and germicide in the vessel solution.

\section{Acknowledgments}

To the company Terra Viva Flowers and Plants (Vargem Grande do Sul, SP) for the supply of te plant material and to the CAPES (PEC-PG) by granting $\mathrm{PhD}$ scholarship to the first author.

\section{References}

Aghdam MS, Hassanpouraghdam MB, Paliyath G, Farmani, B (2012) The language of calcium in postharvest life of fruits, vegetables and flowers. Scientia Horticulturae 144:102-115. 
Akbudak B, Murat S (2012) Effects of preharvest and postharvest calcium and modified atmosphere treatments on vase life of gerbera. Journal of Food, Agriculture \& Environment 10(3-4):968-971.

Amini S, Jafarpour M, Golparvar A (2013) Effect of pulsing treatments (calcium chloride + sucrose and distilled water) with fixed hormonal treatments on postharvest quality of cut Gerbera flowers. Technical Journal of Engineering and Applied Sciences 3(13):1120-1123.

Baas R, Marissen N, Dik A (2000) Cut rose quality as affected by calcium supply and translocation. Acta Horticulturae 518:45-54.

Bai J, Xu P, Zong C, Wang C (2009) Effects of exogenous calcium on some postharvest characteristics of cut gladiolus. Agricultural Sciences in China 8(3):293-303.

Chutichudet B, Chutichudet P (2012) Influence of calcium solutions to physiological changes of 'Chiang Mai Pink' patumma cut flowers. International Journal of Agricultural Research 7(3):121-133.

Dayod M, Tyerman S, Leigh R, Gilliham M (2010) Calcium storage in plants and the implications for calcium biofortification. Protoplasma 247:215-231.

Dias SMF, Patil AA (2003) Chemically fortified solutions to enhance the longevity of cut roses Cv. Arjun. Karnataka Journal of Agricultural Science 16(2):324-326.

Ezhilmathi K, Singh VP, Arora A, Sairam RK (2007) Effect of 5-sulfosalicylic acid on antioxidant activity in relation to vase life of Gladiolus cut flowers. Plant Growth Regulation 51: 99-108.

Frickle W (2004) Solute shorting in grass leaves: the transpiration stream. Planta 219:507-514.

Gilliham M, Dayod M, Hocking B, Xu B, Conn S, Kaiser B, Leigh R, Tyerman S (2011) Calcium delivery and storage in plant leaves: exploring the link with water flow. Journal of Experimental Botany 62(7):2233-2250.

González-Aguilar S, Zavaleta-Mancera A (2012) El $\mathrm{CaCl}_{2}$ en la vida de florero de gerbera: pigmentos, fenoles, lignina y anatomía del escapo. Revista Mexicana de Ciencias Agrícolas 3(3):539-551.

Hatamzadeh A, Shafyii-Masouleh S (2013) Nanosilver pulsing and calcium sulfate improve water relations on cut gerbera flowers. South Western Journal of Horticulture, Biology and Environment 4(1):1-11.

Hepler PK (2005) Calcium: A central regulator of plant growth and development. The Plant Cell 17:2142-2155.

Huerta $M$, Arriaga A, González S, Mandujano M, Guzmán G, Gracián S (2011) The effects of calcium on postharvest water status and vase life of Rosa hybrid cv. Grand Gala. International Journal of Agriculture \& Biology 13:233-238.
Imsabai W, Leethiti P, Netlak P, van Doorn W (2013) Petal blackening and lack of bud opening in cut lotus flowers (Nelumbo nucifera): Role of adverse water relations. Postharvest Biology and Technology (79):32-38.

Kerton M, Newbury H, Hand D, Pritchard J (2009) Accumulation of calcium in the center of leaves of coriander (Coriandrum sativum L.) is due to an uncoupling of water and ion transport. Journal of Experimental Botany 60(1):227-235.

Lin R, Kuo M (2008) Ethylene biosynthesis and membrane microviscosity changes of cut rose Rosa hybrid L. 'Noblesse' by calcium chloride pulse and dry cold storage. Acta Horticulturae 768:469-474.

Mortazavi N, Naderi R, Khalighi A, Babalar M, Allizadeh $\mathrm{H}$ (2007) The effect of cytokinin and calcium on cut flower quality in rose (Rosa hybrid L.) cv. Illona. Journal of Food, Agriculture \& Environment 5(3\&4):311-313.

Rubinstein B (2000) Regulation of cell death in flower petals. Plant Molecular Biology 44:303-318.

Sairam R, Vasanthan B, Arora A (2011) Calcium regulates gladiolus flower senescence by influencing antioxidative enzymes activity. Acta Physiologiae Plantarum 33:1897-1904.

Serek M, Jones R, Reid M (1994) Role of ethylene in opening and senescence of Gladiolus sp. flowers. Journal of American Society for Horticultural Science 119(5):1014-1019.

Silva, JAS (2003) The cut flower: Postharvest considerations. Online Journal of Biological Sciences 3(4):406-442.

Silva ATC, Ferreira VM, Graciano ESA, Souza RC, Araújo Neto JC, Loges $V$ (2009) Postharvest of pink ginger floral stems treated with silver thiosulphate, sucrose, and calcium. Horticultura Brasileira 27:357-361.

Singh A, Kumar J, Kumar P (2008) Effects of plant growth regulators and sucrose on postharvest physiology, membrane stability and vase life of cut spikes of gladiolus. Plant Growth Regulation 55:221-229.

Van Doorn W (2011) The postharvest quality of cut lily flowers and potted lily plants. Acta Horticulturae 900:255-264.

White P, Broadley M (2003) Calcium in plants. Annals of Botany 92:487-511.

Yang H, Jie Y, Shao X (2011) Regulation of calcium uptake and translocation in plants. Acta Horticulturae 903:1011-1016. 